\title{
The Construction of Transnational Remembrance in the War Cemeteries of the Twentieth Century
}

\author{
Kate Clarke Lemay 1 \\ National Portrait Gallery, Smithsonian \\ LemayK@si.edu
}

\begin{abstract}
In the anniversary years of 2018 and 2019, it is important to take a close look at the war cemeteries commemorating the world war conflicts. These sites are crucial places for sustaining and even creating transnational, collective memory. By studying the memory work the war cemeteries accomplish, scholars have increased their knowledge of and understanding about these driving, foundational power structures. The following essays focus on the construction, design and reception of war cemeteries, and together the essays reveal complex layering of social, political and cultural contexts of these crucial sites of war memory.
\end{abstract}

\section{Keywords}

collective memory - World War II - war cemeteries - diplomacy - prisoners of war memory gardens - memorialisation - monuments - D-Day

1 Kate Clarke Lemay earned a dual PhD in art history and American studies from Indiana University, Bloomington. Her book, Triumph of the Dead: American WwII Cemeteries, Monuments and Diplomacy in France was published by the University of Alabama Press in 2018. She has authored peer reviewed essays including those published by The Journal of War and Culture Studies, the University of North Texas Press and the Marine Corps History Division. She is a historian and curator at the Smithsonian's National Portrait Gallery, and resides in the Washington, D.C. area. 


\section{Introduction: War Cemeteries as Agents of Collective, Transnational Memory}

As 2018 and 2019 are major anniversary years for both world war conflicts, it is worth noting that war cemeteries have endured to become among the most symbolic of war's costs, even as they mask some realities. Material culture, or the monument, creates significant meaning and memory of war to such a degree that it is a major force driving public recollection. As the following essays argue, the war cemeteries in Europe, monuments and their landscapes help to revise and even create public memory. Indeed, these monuments reconstruct the past through the lens of the present. ${ }^{2}$ As the conflicts of the twentieth century fade-and those veterans and survivors with "living memory" become fewer-it is important to take a close look again at the war cemeteries.

In the 1980s, a great uptick in the number of memorials to the conflicts of the First and Second World Wars became part of, to borrow historian Jay Winter's phrase, an era of a "memory boom". ${ }^{3}$ Individuals, associations and communes engaged in commemorative efforts and the public seemed to not be able to have enough of these markers. Art historian Erika Doss argues that the urge to remember in the contemporary United States reflects a kind of emotional mania, as present-day Americans increasingly need to understand their national and local histories as expressions of grief, fear, gratitude, trauma and anger. ${ }^{4} \mathrm{An}-$ other art historian, Kirk Savage, demonstrates how memorial-making belies political power plays, as in the recent monuments constructed in the National Mall in Washington D.c. ${ }^{5}$ Given the layering of social, political and cultural contexts behind collective memory as it is presented in material forms, it is helpful to examine and analyse some of the very beginning moments of the boom: the war cemeteries of the twentieth centuries located in Europe.

The geographic region of France serves well as a kind of case study. As the site of many battlefields, after both World Wars, France was host to many graves of soldiers from all nations. As the keeper of historic sites, the French government exerted strict control in how many memorials were made to war, and for whom. For example, until 1968, all French-designed monuments in

2 Collective memory was defined by Maurice Halbwachs. See Maurice Halbwachs, On Collective Memory, trans. Lewis A. Coser (Chicago, 1992).

3 Jay Winter, Remembering War: The Great War Between Memory and History in the Twentieth Century (London, 2006), 38-39.

4 Erika Doss, Memorial Mania: Public Feeling in America (Chicago, 2010).

5 Kirk Savage, Monument Wars: Washington, D.C., the National Mall, and the Transformation of the Memorial Landscape (Oakland, CA, 2009). 
France commemorating the Second World War first had to get approval from the national government, a laborious process involving two separate committees and many figureheads. A departmental commission for the purpose of approval of a monument was consulted, and they in turn were counselled by a national commission. Each commission had more than sixteen members, and had only two months for the approval process. ${ }^{6}$ As memorials were proposed, politics, rather than an even-handed consideration of all memorials, was the force behind determining which were to be realized. Henry Rousso describes how post-war era government officials considered French civilian deaths as "inappropriate" for traditional forms of commemoration. ${ }^{7}$ The topic of civilian death has only recently been addressed in scholarship by Mary Louise Roberts and in museum exhibitions like that of the Mémorial de Caen Peace Museum. ${ }^{8}$

French control of memorials included cemeteries, where diplomacy was also at play. Though the Commonwealth and American war cemeteries were guided by agencies of their own nations, conversely, the Treaty of Versailles gave the French administrative control over German cemeteries from the First World War (and this was extended after the Second World War). For German burials not performed by the American Graves Registration Service, often the fallen Germans were left unmarked in the ground. After the Second World War, during the late 1950s through the 1980s, private German associations searched the territory for their lost soldiers. The Nazis had planned to create Totenburgen, or fortresses of the dead, but of course their designs were never realizedat least, not by the German military. Instead, ossuaries were made, some in the spirit of Totenburgen like the ossuary Huisnes-sur-Mer near Saint James in Lower Normandy, but more simple in their design. Robert Tischler, the lead architect hired by the Volksbund Deutsche Kriegsgräberfürsorge, was overwhelmed, and subsequently had to rely on a Bauhütte, a collective workshop modelled after the system of the medieval era, to help him execute the many designs. By the end of the 1980s, the Volksbund Deutsche Kriegsgräberfürsorge had created 190 German cemeteries and ossuaries for the fallen German soldiers from the Franco-Prussian War, the First World War and the Second World War. ${ }^{9}$

6 Jacqueminede Loizellerie, "Les lieux de mémoire de la Seconde Guerre mondiale dans la manche", Mémoire de maitrise, Université de Caen, 1998, 34-36.

7 Henry Rousso, The Vichy Syndrome: History and Memory in France since 1944, trans. Arthur Goldhammer (Cambridge, MA, 1991), 22-24.

8 Mary Louise Roberts, What Soldiers Do: Sex and The American GI in World War II France (Chicago, 2012).

9 The Treaty of Versailles gave the French administrative control over German cemeteries from the First World War. See Anne Biraben, Les cimetières militaires en France: Architecture et paysage (Paris, 2005), 86. According to Gavin Stamp, the French did not allow the Germans to 
The Commonwealth War Graves Commission maintains cemeteries for the fallen British, Canadian, Australian, and other soldiers of the United Kingdom. These cemeteries are unified in design by the inclusion of the Sword of Sacrifice, and, if containing more than 1000 graves, a Stone of Remembrance-both symbolic of power, religion, and the state; both working to contain trauma. These forms are usually the only decorative elements of art and architecture within the Commonwealth landscape. ${ }^{10}$ However, the landscape of the typical Commonwealth cemetery includes an unbroken row of wildflowers and flowering bushes in front of the line of headstones. For the war cemeteries of the Second World War, for example, one million, three hundred plants were issued to the cemeteries in France and Belgium in 1937. These plants were placed in front of the headstones, achieving a rambling and wild English garden aesthetic.

The United States is the only nation to have constructed major works of art and design into its war cemeteries. After both world wars, two of its federal agencies, the American Battle Monuments Commission and the Commission of Fine Arts, worked together to hire a different set of architects, sculptors and muralists for each cemetery. The American cemeteries from the Second World War each include a battle map mural within its boundary. This is an important difference from the American cemeteries of the First World War in that their aesthetic programming sets up the dead to be read symbolically as martyrs fallen during battle in their quest for global democracy. Nevertheless, both sets of cemeteries after each war included monumental works of architecture, in part to serve as a reminder to the Allies, Britain and France, that the United States was there, as well. British and French war memorials were everywhere, and in such an environment of material culture and memory, the United States had to leave its mark.

\section{Types of Memory: Collective versus Individual in the Graves' Headstones}

In the preservation of the memory of the individual soldiers, the Commonwealth stands apart from the other nations. Commonwealth war graves present

construct their own cemeteries, but the Belgians did. See Gavin Stamp, "Almost Unbearable: German Architecture after World War I”, Apollo. 166 (548) (2007): 72.

10 See Edwin Gibson and G. Kingsley Ward, Courage Remembered: The story behind the construction and maintenance of the Commonwealth's Military Cemeteries and Memorials of the Wars of 1914-1918 and 1939-1945, (London, 1989). 
the loss of the fallen on a personal level, describing the loss in words chosen by the next-of-kin on each headstone. By contrast, the American headstone relays little information beyond national signifiers, and the German and French headstones only declare the dead's life-dates. ${ }^{11}$ The Commonwealth headstone allows for inscribed epitaphs in French, Hebrew or other languages, depending on the soldier's home culture. The Suresnes American Cemetery outside of Paris, as well as the Oise-Aisne American Cemetery in the Oise, are two instances in which American cemeteries allowed for inscriptions on the grave markers. Families were allowed to choose an epitaph composed of sixty letters, but they had to finance the cost, and the result skewed the personalization of only wealthy dead soldiers. ${ }^{12}$ If one looks closely at those grave markersabout twelve in total at each site- the inscriptions reveal more about the privilege and culture of the family than they do about the fallen soldier himself. The selections made for the engravings were usually citations of poetry from such accomplished writers like Shakespeare, the $18^{\text {th }}$ century Scottish poet Thomas Campbell, or the $20^{\text {th }}$ century British poet John Masefield. These poets were, at the time, indicators of a very privileged education, and perhaps were understood as cues relating the social standing of the fallen soldier. The other trend was to highlight the fallen had died while actually in combat with the engraved words, "Killed In Action." In other words, the killed-in-action soldier was recognized as more of a hero than the soldier who died from, for example, an infectious disease or influenza.

Given how death was becoming an opportunity for the privileged to express themselves as such, the United States government decided to eliminate, altogether, the opportunity for personalization. Perhaps due to the biased character of the inscriptions, the engraved information was reduced to only the identification, thereby emphasizing information that underscores the individual fallen as part of a national collective. The reduced information was thought to be a kind of levelling device, intoning that all soldiers are equal in death. The omission of the date of birth makes it impossible to personalize the

11 After the First World War, the Commonwealth Graves Commission spent about five English pounds per headstone, and the various governments of the Commonwealth paid in proportion to the number of graves each required. There were six hundred thousand headstones set in two hundred and fifty miles of headstone beams and eighteen larger memorials to the missing. Although the budget was ten million pounds, the actual expenditure was only eight million, one hundred and fifty thousand pounds. See Gibson and Ward, Courage Remembered, $55^{-57}$.

12 See Durable Markers in the Form of Crosses for Graves of American Soldiers in Europe. Hearing Before the Committee on Military Affairs, House of Representatives, Sixty-Eighth Congress, March 1924 (Washington, D.C., 1924). 
fallen, even by approximating his or her age. In this narrative, the individual is subsumed by the nation, as the emphasis serves to perpetuate high ideals identified as American. The basic information that is provided on the American headstone has much in common with that of the German headstone. The latter, however, is more revealing because it allows for the viewer to understand the age upon death.

The headstones of each nation's war cemeteries are visual signifiers of the fallen, and over time, they have managed to present an idea of a whole person rather than a maimed, killed, infected and diseased body of the soldier dead. The fallen from these cemeteries are purified in death, ever sustaining what George L. Mosse defines as the cult of the fallen soldier. ${ }^{13}$ As the brief examination of headstones above illustrates, study of the construction and design histories of war cemeteries reveals strategies of remembrance that are still at play to this day. What were the contexts of the cemeteries at the time of their inception? How do they inform what was built, and what influences are there behind the messaging of each nation? Are there histories that have been overlooked, and if so, why?

\section{The War Cemeteries: Prisms for Transnational Memory}

Although the literature on the First and Second World Wars is vast, scholars have just begun to tackle, in rigorous ways, the various nations' war cemeteries in Europe. ${ }^{14}$ One fresh direction to study war memorials is to study the

13 George L. Mosse, Fallen Soldiers: Reshaping the Memory of the World Wars (New York, 1990), 50 .

14 For the Commonwealth war cemeteries, see Philip Longworth, The Unending Vigil: The History of the Commonwealth War Graves Commission (London, 1967); Gavin Stamp, Silent Cities: An Exhibition of the Memorial and Cemetery Architecture of The Great War (London, 1977); Ewin Gibson and G. Kingsley Ward, Courage Remembered (London, 1989); David Crane, Empires of the Dead: How One Man's Vision Led to the Creation of WwI's War Graves. (London, 2014); for the American war cemeteries, see Sam Edwards, Allies in Memory: World War II and the Politics of Transatlantic Commemoration, c.1941-2001 (Cambridge, 2015); Antonin Dehays, Combattre et Mourir en Normandie: Les GI's et l'expérience au feu | De la mort à la mémoire - Normandie 1944 (Bayeux, 2017); Kate Clarke Lemay, Triumph of the Dead: American World War II Cemeteries, Monuments and Diplomacy in France (Tuscaloosa, AL, 2018); for French war cemeteries and monuments, see Mechtild Gilzmer, Mémoires de pierre: Les monuments commémoratifs en France après 1944, trans. Odile Demange, preface by Serge Barcellini (Paris, 2009); for German war cemeteries, see Christophe A. Mauriello, Forced Confrontation: The Politics of Dead Bodies in Germany at the End 
construction histories of war cemeteries. Another invigorating approach is to consider them as places with important design histories. A third way is to investigate how they, as sites of memory, sites of mourning and sites of design, work to influence international diplomacy. Only recently has work by Sam Edwards and Michael Dolksi begun to open up the field in these directions. ${ }^{15}$ Although political historian Ron Robin endeavoured to take American war cemeteries into account as foreign "enclaves", he dismissed them outright as bad art and propaganda pieces. ${ }^{16}$ Whereas Jane C. Loeffler's influential study considers architecture's potential to wield cultural diplomacy, she focused solely on embassies. ${ }^{17}$ With the exception of Christian Fuhrmeister and Kai Kappel, few scholars have endeavoured to create a transatlantic comparison of war cemeteries involving more than two countries. ${ }^{18}$ The following essays endeavour to pay special attention to the historical, political, and social factors that affected the design of various nations' war cemeteries. They take into account the construction, maintenance and influences of the war cemeteries, producing scholarship that demonstrates how war cemeteries have played a major part in both the creation and sustainment of the cultural memory of twentieth century world wars; forged post-war national identities; and facilitated international diplomacy.

Zoë Rose Buonaiuto introduces the topic with her essay, "A Grave Reconciliation:The Establishment of German War Cemeteries in Normandy, 1944-1964", which explores the politics behind making amends after such a terrible war. She writes of "the power of dead Germans on French soil", examining how the matter of decorating a grave during the immediate post-war opened up angles of resentment and reconciliation from all sides. With an eye to the French, who experienced everything in their own backyards, Buonaiuto reveals how Normans grappled with burying and commemorating German war dead. Yet, she argues, Franco-German reconciliation depended upon the maintenance

of World War II (Lanham, MD, 2017); Bill Niven and Chloe Paver, eds., Memorialization in Germany Since 1945 (New York, 2010).

15 Michael Dolski, Sam Edwards and John Buckley, eds., D-Day in History and Memory. (Denton, TX, 2014).

16 Ron T. Robin, Enclaves of America: The Rhetoric of American Political Architecture Abroad, 1900-1965 (Princeton, NJ, 1992).

17 Jane C. Loeffler, The Architecture of Diplomacy: Building America's Embassies (New York, 1998).

18 Fuhrmeister Christian and Kai Kappel, eds., "War Graves/Die Bauaufgabe Soldatenfriedhof, 1914-1989", Journal of the International Association of Research Institutes in the History of Art (June 2017). 
of war graves-a bittersweet affair as, within the contexts of the immediate post-war era, it may be considered as "honouring its Nazi past". Moreover, as Buonaiuto concludes, the presence of Germans in France, even buried deep underground, still creates something like an "occupation".

In his essay, "Burying Friend or Foe: The Employment of German Prisoners of War in the Construction of Military Cemeteries in Normandy after 6 June 1944", Valentin Schneider explores the details of what constructing a war cemetery really meant - for the vanquished. Outlining the massive numbers of German "Pows" - the Allies captured three times more than they expectedSchneider explains the peculiar circumstances of German Pows being put to work digging graves for their countrymen as well as for their enemy. Pointing out that prisoners of war could not manufacture weapons or facilitate war in any other way, Schneider's essay outlines the interconnected histories of the prisoners and of the burial of the dead. He places these contexts into the politics of the local French people, who resented losing out on possible work, because they wanted to perform the duties themselves, for a fee. Every citizen of every nation involved felt their own surreal realities in these circumstances. The irony German prisoners of war must have felt when they were creating graves for the very men they had helped kill reflects the great paradox of war, as well as its tragedies.

When the cemeteries were made permanent, with appropriate memorials, art and architecture, they took their own role in diplomacy. The mid-century hysteria against Communism during whose contexts of the American war cemeteries were designed, foreshadow American media frenzy in 2018. Kate Clarke Lemay demonstrates that the American war cemeteries in France resolved difficult international relations in the post-war through "soft power" and cultural diplomacy, asserting that the religious symbolism of the cemeteries created a "Christ-like heroism". She describes how variables of politics, art and religion informed the process of designing memorials to the American war dead in the late 1940 s and 1950s. The artists and architects, however, were "dismissed outright from the highbrow estimators of 'good' art", and in some cases, even condemned as "anti-American". Lemay links the cold war hysteria to a similar vein of demagoguery which characterizes American politics in the present, asserting that history, if not repeating itself, has its echoes.

Like the American war cemeteries, those of the Commonwealth also open up a window into mid-century politics. In 1960, the changing of the name Imperial War Graves Commission to the Commonwealth War Graves Commission demonstrates how, for decades, the war graves were, in fact, part of the "informal empire". Sam Edwards describes how the cemeteries, "conceived 
as gardens of England and built as enclaves of Empire [...] are thus expressive of the expansion and contraction of the twentieth century Imperial and post-Imperial state". The construction of Commonwealth cemeteries into amenable locations, like Europe, may not have been difficult, but as Edwards demonstrates, locations such as those in the Far East and North Africa were "an anachronism in stone". These cemeteries, Edwards argues, "suggested the eternal even as the Empire they commemorated collapsed". Edwards relates several eras of colonist history in his analysis of the 1982 Falklands War, the last occasion since 1945 that the British government was charged with burying its dead overseas. Even in the midst of critiques and anti-colonialism, in the end, he argues, state power dictated the way the dead would be interred.

In addressing these issues within the context of war memory, this special issue's arguments are rooted theoretically in Thomas W. Laqueur's "work of the dead", considering the dead body as a socio-political agent; Maurice Halbwachs' ideas of collective memory, which argue that the past is a social construction mainly shaped by concerns of the present; Pierre Nora's argument for the power of place in sustaining collective memory; Michel Foucault's concepts about knowledge of trauma and the subsequent and necessary control of memory Finally, Paul J. Fussell's ideas that the First World War's commemorative response outlined a new, "modern memory"; whereas Jay Winter argued that the First World War's memorials reframed traditional ideas of mourning. ${ }^{19}$

War cemeteries reveal how different nations dealt with the logistical nightmare of burying and honouring literally hundreds of thousands of dead bodies, humans killed during the act of fighting for a country. The ways in which the victors of conflict commemorate their "soldier dead", to borrow Michael J. Sledge's term, is a world apart from the systems to which the vanquished resorted. ${ }^{20}$ Study of war's remembrance in material culture opens up the field of military history to new ways of understanding the significance of combat and its consequences.

19 Thomas M. Laqueur, The Work of the Dead (Princeton, 2015); Michel Foucault, Discipline and Punish (New York, 1977); Maurice Halbwachs, On Collective Memory, trans. Lewis A. Coser (Chicago, 1992); Pierre Nora, Realms of Memory, trans. Arthur Goldhammer (New York, 1996); Paul Fussell, The Great War and Modern Memory (Oxford, 200o); Jay Winter, Sites of Memory, Sites of Mourning (Cambridge, 1995).

$20 \quad$ Michael Sledge, Soldier Dead: How We Recover, Identity, and Burial Our Military Dead (New York, 2005). 


\section{Bibliography}

Biraben, Anne. Les cimetières militaires en France: Architecture et paysage (Paris: L'Harmattan, 2005).

Gibson, Edwin and G. Kingsley Ward. Courage Remembered: The story behind the construction and maintenance of the Commonwealth's Military Cemeteries and Memorials of the Wars of 1914-1918 and 1939-1945 (London: Her Majesty's Stationery Office, 1989).

Crane, David. Empires of the Dead: How One Man's Vision Led to the Creation of WWI's War Graves. (London: William Collins, 2014).

Dehays, Antonin. Combattre et Mourir en Normandie: Les GI's et l'expérience au feu |De la mort à la mémoire - Normandie 1944 (Bayeux: OREP Editions, 2017).

Dolski, Michael, Sam Edwards and John Buckley, eds. D-Day in History and Memory (Denton, TX: University of North Texas Press, 2014).

Doss, Erika. Memorial Mania: Public Feeling in America (Chicago: University of Chicago Press, 2010).

Durable Markers in the Form of Crosses for Graves of American Soldiers in Europe. Hearing Before the Committee on Military Affairs, House of Representatives, Sixty-Eighth Congress, March 1924 (Washington, DC: Us Government Printing Office, 1924).

Edwards, Sam. Allies in Memory: World War II and the Politics of Transatlantic Commemoration, c.1941-2001 (Cambridge: Cambridge University Press, 2015).

Edkins, Jenny. Trauma and the Memory of Politics (New York: Cambridge University Press, 2003).

Foucault, Michel. Discipline and Punish (New York: Pantheon Books, 1977).

Fuhrmeister Christian and Kai Kappel, eds. "War Graves/Die Bauaufgabe Soldatenfriedhof, 1914-1989", Journal of the International Association of Research Institutes in the History of Art (June 2017).

Fussell, Paul. The Great War and Modern Memory (Oxford: Oxford University Press, 2000).

Halbwachs, Maurice. On Collective Memory, trans. Lewis A. Coser (Chicago: University of Chicago Press, 1992).

Laqueur, Thomas M. The Work of the Dead (Princeton, NJ: Princeton University Press, 2015).

Lemay, Kate Clarke. Triumph of the Dead: American World War II Cemeteries, Monuments and Diplomacy in France (Tuscaloosa, AL: University of Alabama Press, 2018).

Loeffler, Jane C. The Architecture of Diplomacy: Building America's Embassies (New York: Princetown Architectural Press, 1998).

Loizellerie, Jacqueminede. “Les lieux de mémoire de la Seconde Guerre mondiale dans la manche", Mémoire de maitrise, Université de Caen, 1998. 
Longworth, Philip. The Unending Vigil: The History of the Commonwealth War Graves Commission (London: Constable, 1967).

Gilzmer, Mechtild. Mémoires de pierre: Les monuments commémoratifs en France après 1944, trans. Odile Demange, Preface by Serge Barcellini (Paris: Éditions Autrement, 2009).

Mauriello, Christopher A. Forced Confrontation: The Politics of Dead Bodies in Germany at the End of World War II (Lanham, MD: Lexington Books, 2017).

Mosse, George L. Fallen Soldiers: Reshaping the Memory of the World Wars (New York: Oxford University Press, 1990).

Niven, Bill, and Chloe Paver, eds. Memorialization in Germany Since 1945 (New York: Palgrave Macmillan, 2010).

Nora, Pierre. Realms of Memory, trans. Arthur Goldhammer (New York: Columbia University Press, 1996).

Pennebaker, James W., Darío Páez, and Bernard Rimé. Collective Memory of Political Events: Social Psychological Perspectives (Mahwah, NJ: Lawrence Erlbaum Associates, 1997).

Piehler, Kurt. Remembering War the American Way. (Washington, D.C.: Smithsonian Institution Press, 1995).

Roberts, Mary Louise. What Soldiers Do: Sex and The American gI in World War II France (Chicago: University of Chicago Press, 2012).

Roberts, Mary Louise. D-Day Through French Eyes (Chicago: University of Chicago Press, 2014).

Robin, Ron T. Enclaves of America: The Rhetoric of American Political Architecture Abroad, 1900-1965 (Princeton, NJ: Princeton University Press, 1992).

Rousso, Henry. The Vichy Syndrome: History and Memory in France since 1944, trans. Arthur Goldhammer (Cambridge, MA: Harvard University Press, 1991).

Savage, Kirk. Monument Wars: Washington, D.c., the National Mall, and the Transformation of the Memorial Landscape (Oakland, CA: University of California Press, 2009).

Sledge, Michael. Soldier Dead: How We Recover, Identify, Bury and Honor Our Military Fallen (New York: Columbia University Press, 2005).

Stamp, Gavin, "Almost Unbearable: German Architecture after World War I". Apollo 166 (548) (2007): 72.

Stamp, Gavin. Silent Cities: An Exhibition of the Memorial and Cemetery Architecture of The Great War (London: Royal Institute of British Architects, 1977).

Winter, Jay. Remembering War: The Great War Between Memory and History in the Twentieth Century (London: Yale University Press, 2006).

Young, James E. The Stages of Memory:Reflections on Memorial Art, Loss, and the Spaces Between (Amherst, MA: University of Massachusetts Press, 2016). 